\title{
USE OF BIOLOGICAL ADHESIVE FOR EFFECTIVE DUST SUPPRESSION IN MINING OPERATIONS
}

\author{
Aleksandr Sergeevich Danilov' ${ }^{1}$ Yuri Dmitrievich Smirnov ${ }^{1}$, Maria Anatolievna Pashkevich ${ }^{1}$ \\ 1 National Mineral Resources University (Mining University), Vasilyevsky Island 21 line d.2, Saint-Petersburg, \\ 199106, Russia, e-mail: danilovspmi@gmail.com; qwerik84@gmail.com; mpash@spmi.ru
}

Received: 2015.08 .15

Accepted: 2015.10.06

Published: 2015.11.10

\begin{abstract}
This article explores modern methods of reclamation of lands disturbed processes of mining, based on monitoring disturbed lands using unmanned aircraft and dusty surfaces coated biologically active adhesive, biological foam. In the article new highly efficint methods of remote monitoring of environment components are considered on based of unmanned aircrafts. For monitoring, it is suggested to draw complexes based of small unmanned aircraft vehicle, equipped with special equipment (a digital camera, a thermal imaging camera, dust meter). Land reclamation on the biological stage is encouraged by using new bio-adhesives, developed on the basis of polysaccharides and various microorganisms. This composition helps reduce the consumption of fertilizers, pesticides and other components, pioneer in growing crops on dusty surfaces in the disturbed lands. As a result of such an event, dust discharge from the surface technogenic structures is reduced up to 10 times.
\end{abstract}

Keywords: land reclamation, dust, biological adhesive, bio-foam, technogenic structures.

\section{INTRODUCTION}

Accumulation of wastes of booty and processing of minerals and their affecting components of natural environment are one of the main ecological problems of raw mineral-material complex. Annually millions of hectares of fertile earth in the world are alienated under the temporal placing and warehousing of wastes from mining industry.

Mining and mineral processing generate significant dust streams and large areas of disturbed land. According to rough estimates, in Russia the total area devastated by mining operations as a result of coal mining is 190 thousand hectares. With production of ferrous and non-ferrous ores about 350 thousand hectares, in the development of building rocks - more than 290 thousand hectares. Particulate Air Pollution in the areas of intense dust (separating rocks from the array, transport, pouring and forming piles) reaches more than $1000 \mathrm{mg} / \mathrm{m}^{3}$. And the dust most dangerous to humans (less than 10 microns) can hover in the air for several hours and travel long distances, causing silicosis among not only the workers, but also residents of nearby settlements [Smirnov \& Ivanov, 2013].

Today a joint-stock company "Apatite" is a large mining complex whose sphere of activity are booty and enriching of apatite-nephelites ores of Hibiny deposits, production apatite and nephelite concentrates, and also other mineral concentrates - syenite, titaniummagnetite. In the structure of the confirmed world supplies of apatite ores to date the stake of Hibiny deposits makes about 30 percents.

Licenses are granted until 2030 with a right for development within the limits of all contour of the calculated and ratified supplies of apatitenephelite ores.Today in the Khibiny massif explored ten deposits apatite-nepheline ore, the total balance stocks make $3.8 \mathrm{bln}$. tones, $1.5 \mathrm{bln}$. tons - the state reserve.

All productive objects of joint-stock company "Apatite" located in the foot-hills of Hibiny in central part of the Kolsky peninsula, in the 
south part of Hibiny mountain range, in a direct closeness from the cities of Apatit and Kirovsk. Apatite concentrate containing up to 39 percent of phosphorus oxide $\left(\mathrm{P}_{2} \mathrm{O}_{5}\right)$ is used for the production of double and triple superphosphate, phosphoric acid, ammophos, nitrophoska, rareearth elements, fluorine and its connections, and similarly other foods outside joint-stock company "Apatite".

A nephelite concentrate containing no less than 28,5 percent of $\mathrm{Al}_{2} \mathrm{O}_{3}$ is used for the production of aluminum, soda, potash, cement, phosphoric-potassium fertilizers, coagulants of containing an aluminium, brick wares, glass wares, rare-earth elements, different salts of aluminium and other foods outside a joint-stock company "Apatite".

\section{MATERIALS AND METHODS}

Dump is located in the White bay of Imandra Lake at a distance of $8.1 \mathrm{~km}$ from the industrial site concentrator and $9 \mathrm{~km}$ to the northwest of the Apatity city and put into operation in 1963. Initial capacity of Dump formed a separate bulk, primary dikes separating the White lips of the Imandra Lake and a beamed network streams. Further build dams carried alluvial manner with the increasing of the dam were closed, and the current capacity Dump is fenced all around. To date, Dump is one of the largest in Europe in terms of its area and volume: a total area of $8 \mathrm{~km}^{2}$, and the perimeter of the dam embankment - more than 12 kilometers. Dump territory stretched from southeast to north-west and is bounded to the east by Khibiny Mountains, and from the west by Lake Imandra. The dams Dump for 2014 reached a height of $89.4 \mathrm{~m}$. By location Dump flat type, the method of filling - alluvial type.

In the course of field observations in the study area, it was found that the main sources of pollution of environmental components in the operation of the dump structures are:

- dusting beach zone dump: in the air dust waste is released;

- dust the sides of the dam dump: in the air soil dust is released;

- internal dusting highways: the air is released in the dust of ground;

- earthworks at dumping embankment dams: the air is released in the dust of ground;

- work vehicles and road equipment in the air allocated combustion of diesel fuel;
- work on relaying of pipelines: in the air allocated Welding fumes and dust metal.

In fact, dusting a beach is only possible on those sites, which are not made of waste reclamation and remediation performed. In the areas of active reclamation beach area is heavily humid, which eliminates the possibility of dust from the surface. According to field observations of the average area of the dump dusting is 8.2 hectares. In this case, there is no dusting during the year with stable snow cover in the days of "warm" period of the year with precipitation.

Monitoring atmospheric pollution by dust was conducted using a set of environmental monitoring, based on the use of unmanned aerial vehicles equipped with instrumentation payload.

Methodology of realization of monitoring with the use of UAF is developed to the research object, its size, extent, level and nomenclature of contaminating components of the environment. This methodology was rationally applied during the realization of monitoring of the state of atmospheric air in the districts of location of point and area sources of contamination in the atmosphere.

The monitoring program includes the control of concentration of contaminants in the upper atmosphere and the total deposit of source contamination in the lower atmosphere, the trajectory of the flight is determined as the area of the source of pollution, and also by technical capabilities of unmanned aircraft, defining the maximum length of a possible flight of unmanned aircraft [Pashkevich et al., 2015]. The studies of the atmospheric conditions in the area of the dump were built upon mathematical models of the distribution of the concentration of dust particles, presented in Figure 1.

Fractional analysis of waste, made using laser scattering particle size distribution analyzer, stored in the ponds showed that waste products are presented as submicron particles having the most negative impact on human health. Analytical data presented in Figure 2.

The main reason for the low soil fertility dumps, in particular - sand, is a negligible content of clay fraction. Since batteries are concentrated mainly in the clay fraction, i.e. sandy soils, which always have a lower content of these elements than their middle and heavy mechanical structure. Therefore, to ensure crop nutrients, sandy soil to a greater extent than others requires the application of organic and mineral fertilizers. But due to lack of content in the clay fraction of man-made arrays 


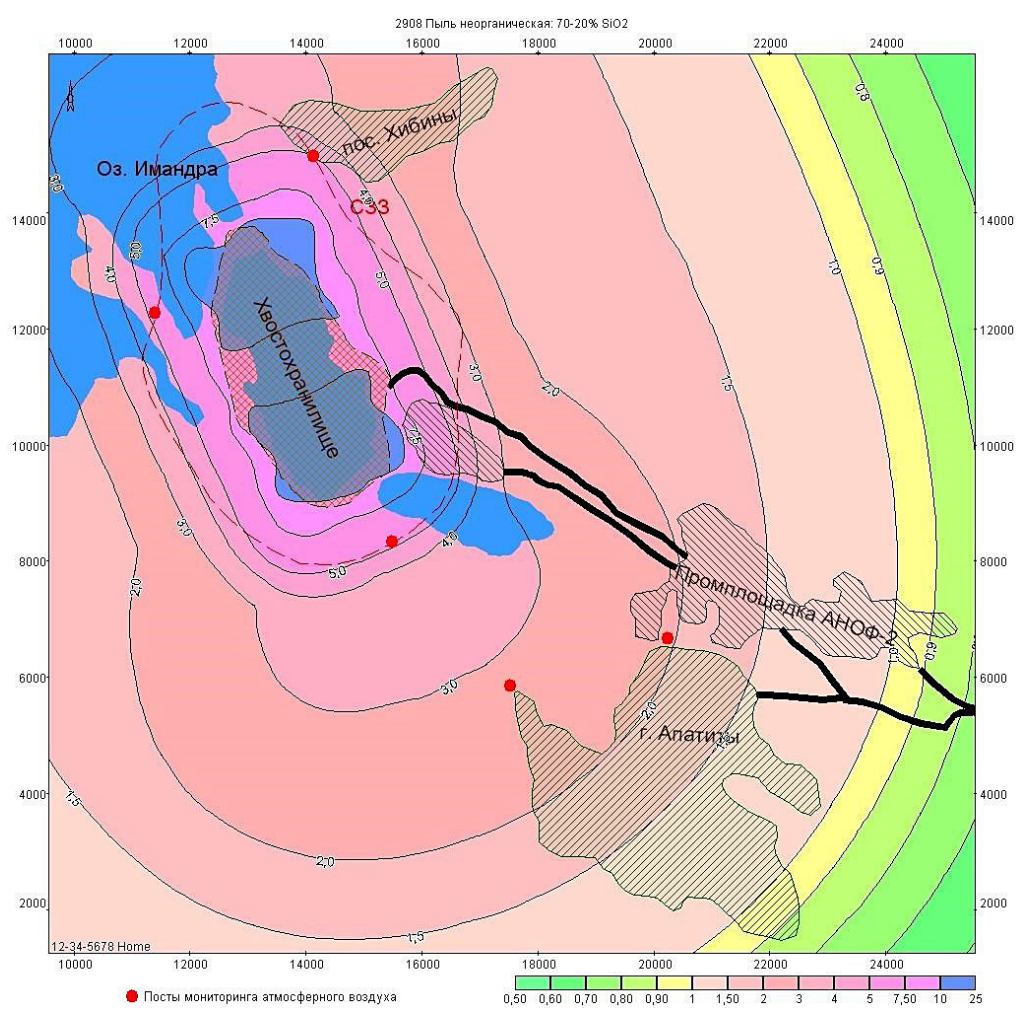

Figure 1. Distribution of dust concentration during adverse weather conditions (PC program "Ecolog 2.0")

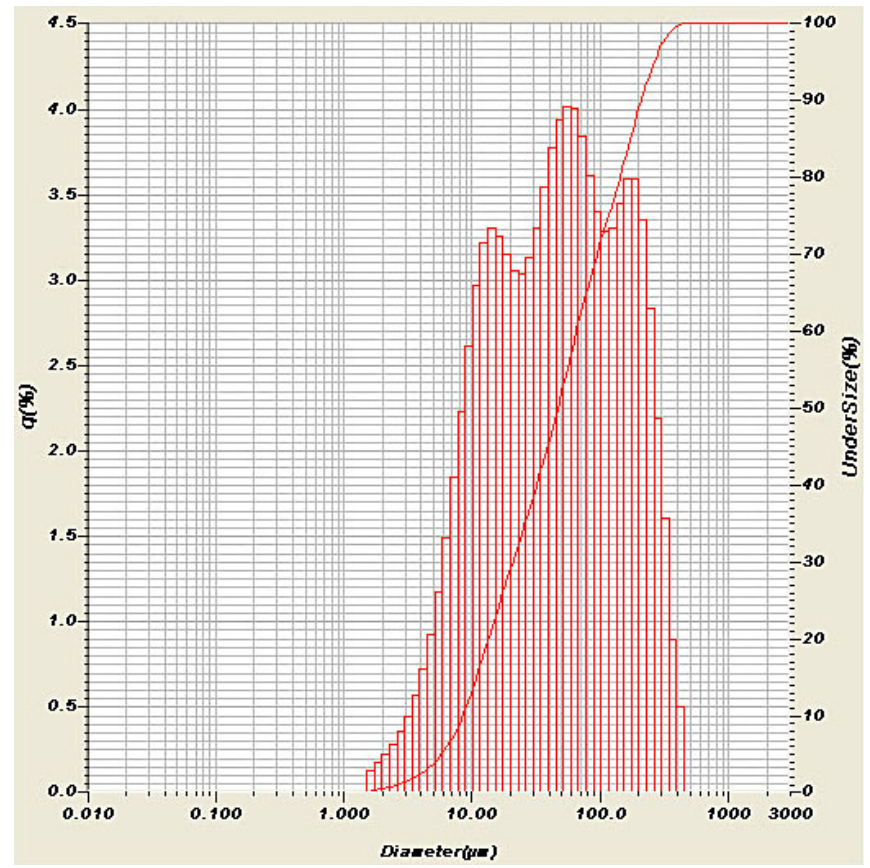

Figure 2. fractional composition of waste landfilled in a dump

absorption capacity of these soils is low, while the water permeability, on the contrary, is very high. Therefore, they cannot hold significant reserves of water, and water plants is almost entirely dependent on the frequency of precipitation [Shtin, 2005; Smirnov \& Ivanov, 2013].

Figure 3 shows typical methods of dust control area sources, which are divided into biologically in- effective and biologically effective (methods with elements of biological remediation). On the basis of the laboratory complex of the Mining University new ways of dust suppression are developing.

To reduce the anthropogenic impact prevailing in the region as a result of the operation of dump, the company proposed to introduce a number of environmental measures aimed at re- 


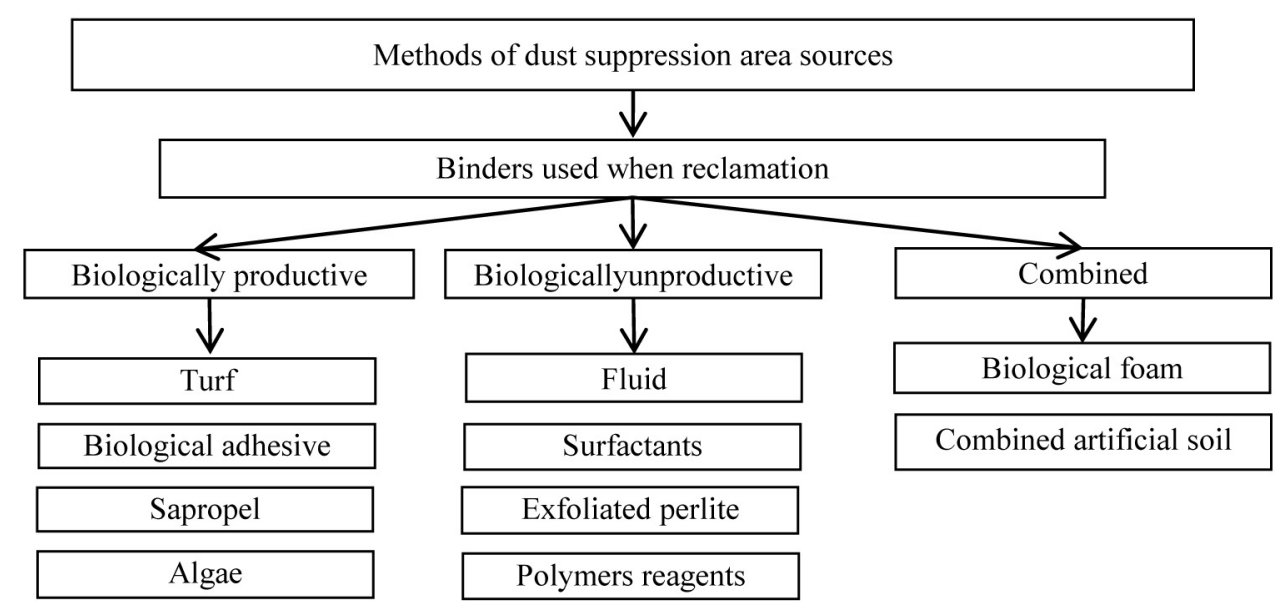

Figure 3. Typical methods of dust control area sources

ducing dust emissions from the surface of the beaches and the sides of the dam dump, as well as from the surface of the internal production on motorways. In order to secure beaches dump universal biological adhesives of the main and most effective environment protection measures that may be applied to the production facility under consideration.

As a biological adhesive the drug EPAA and its commodity form EPAA-10 are encouraged to use, developed at the Institute of Microbiology and Virology Zabolotny National Academy of Sciences of Ukraine. They are created on the basis of certain microbial polysaccharides and safe chemical components. In toxicity parameters it relates to non-toxics substances, the relevant class IV safety. Compared with other analogues EPAA-10 has the following advantages:

- a compound of biological origin highly contributing to the adhesion of pesticides, growth regulators, etc. to seeds and vegetative plants;

- fixes useful plant flora;

- increases drought resistance of plants and their resistance to frost and stress;

- increases the validity of pesticides, growth stimulants;

- prolong the beneficial bacteria that are part of the microbial preparations;

- highly soluble in water and has a high gluing ability;

- increases plant resistance to root rot, bacterial and fungal diseases;

- increases the effectiveness of pesticides;

- rates of pesticides to reduce by more than $30 \%$, and the number of treatments of plants with pesticides - more than 2 times;

- stimulates plant growth;
- creates a durable film on the plants, preventing their gas exchange;

- environmentally friendly, natural microbial communities decomposes different soil types within 90 days [Volcelko et al., 2011].

All of the above benefits are confirmed by studies during the period 2009-2014 on the state of agricultural research stations and centers of scientific support for agricultural production of different soil and climatic zones.

The proposed action is applied to the surface of the dump beaches biological glue using trailing nozzle distributor. As the traction means, it is proposed to use a bulldozer crawler. Drying on the surface of the dump it forms a film of biological glue, as amended in plant seeds (thickness up to $1-3 \mathrm{~mm}$ ) strength of not less than $0.2 \mathrm{MPa}$. With wind speeds of up to $12-15 \mathrm{~m} / \mathrm{s}$ and the integrity of the structure of the biological effectiveness of the environmental film event reaches $90-95 \%$. Securing the sides of the dam spoil in this method involves the incorporation perennial grasses - Elymusarenarius $L$. into the structure of biological glue. This is quite effective, and most importantly durable. 2-3 years grassland forms a dense network of root system, which secures the top layer of the bulk of the dam and reduces the intensity of dusting dam dump. The only drawback of this abatement measures is a long period of full expansion of Elymusarenarius L., during which there is partial dusting sides of the dam dump [Shuvalov et al., 2007].

To increase the efficiency of dust control as well as for the isolation of toxic dumps, it is recommended to use foam-based bioactive biological adhesive capable of forming a chain (glued). For foam reaction mixture applied on the basis of 
the gassing of aluminum powder which reacts with calcium hydroxide in aqueous medium releases hydrogen, and [Shuvalov and Smirnov, 2006]:

$$
2 \mathrm{Al}+3 \mathrm{Ca}(\mathrm{OH})_{2}+6 \mathrm{H}_{2} \mathrm{O}=\mathrm{Ca}_{3}\left\lfloor\mathrm{Al}(\mathrm{OH})_{6}\right\rfloor_{2}+3 \mathrm{H}_{2} \uparrow
$$

The main components of biological foam is a biodegradable glue, sapropel, shredded waste flour milling and grain industry (straw, leaves, reeds, bark) and additional binder carboxymethylcellulose. Using waste flour and grain processing is undoubtedly rational. The number of secondary resources in the above industries is as high as $90 \%$ of the feedstock. It is also possible to use milled peat.

\section{RESULTS}

Experiments in the laboratory have shown high stability and bio-activity of the resulting bio-foam. Experiments have shown that after 3-4 hours the reaction is stopped and the resulting gassing foam gets maximum multiplicity. The foam fully cures within 30-45 days. On the surface, there is a dense crust, which is not destroyed in the process of watering and subsequent draining, protecting the soil surface by sputtering and destruction due to precipitation.

We can distinguish three layers forming a bio-foam: lower - consists of excess water and adhesive, penetrating into the surface layer dusting dump, securing it, the top - own bio-productive layer of foam, and among them - the reaction product of gasification - Torvaldsons aluminate crystals which further cemented surface of the dump.
Germination of grass planted in a foam layer capacity of up to $3-5 \mathrm{~cm}$ in the laboratory ranges of $70-95 \%$. Figure 4 shows the dependence of the dust discharge from the surfaces of man-made arrays of air flow rate 2 hours after irrigation methods considered.

The results of the research present an exponential dependence of the dust discharge from the surfaces of man-made arrays of air flow rate: for a surface without the use of dust suppression methods for surface fixed biological adhesive to the surface of the fixed bio-foam. Thus, when using methods developed dust is reduced by more than 10 times.

District location reporting enterprise belongs to the zone of the subarctic climate with long severe winter (November-March) and short, cool summers (June-August), and is determined mainly mountainous terrain, which is the cause of the instability of the weather, frequent and strong winds (up to $25-30 \mathrm{~m} / \mathrm{s}$ ) and an abundance of precipitation. The temperature regime during the year is unstable, which causes frequent thaws in winter and in summer frosts and snowfalls.

In the foothills of the Khibiny, wind speed and the stability of its direction is largely dependent on local conditions of the relief. Zonation observed climatic conditions: air temperature drop, an increase in precipitation, wind and snow cover duration with increasing altitude. A characteristic feature of the weather is its instability and rapid change caused by frequent changes of air masses moving cyclones and fronts. Monsoonal wind is weak. In general, for the year winds east-west direction (48\%) prevails over the meridian (11\%).

The proposed variant of dust suppression satisfactorily tested in these climates and therefore

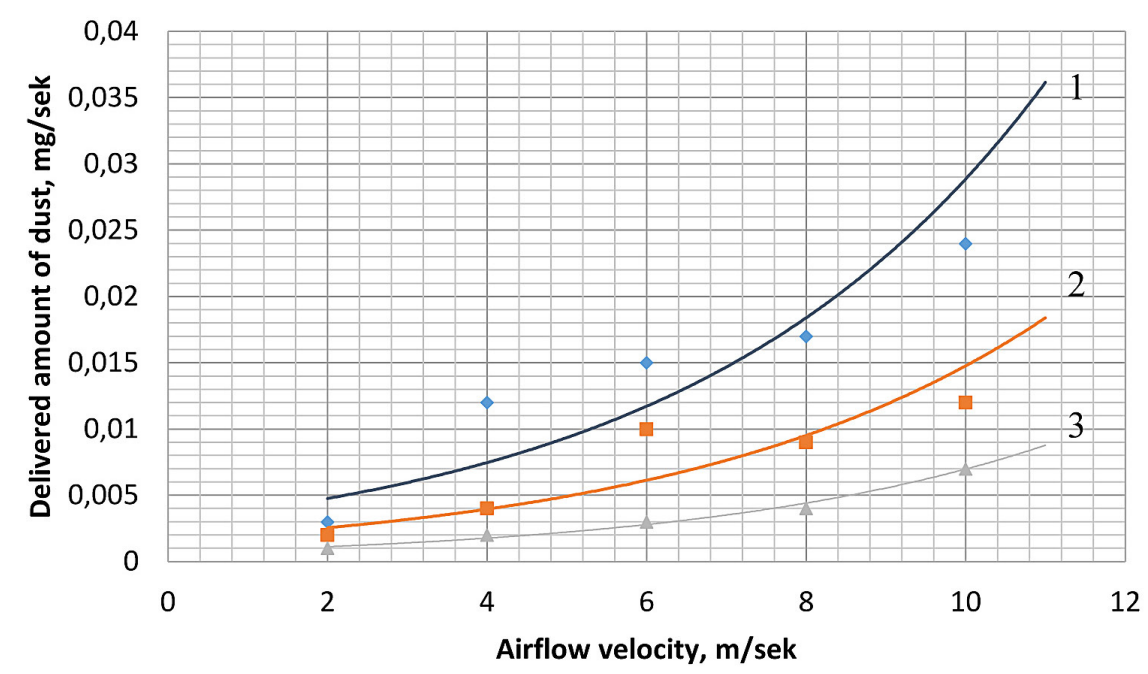

Figure 4. Dependence of the dust discharge from the surfaces of man-made arrays of air speed stream 2 hours after irrigation: 1 - nomeasures, 2 - strengthening biological adhesive, 3 - strengthening biofoam 
can be applied in similar enterprises located in northern and central Europe.

\section{CONCLUSION}

Using waste flour and grain processing industries undoubtedly rationally. The number of secondary resource in the above industries as high as $90 \%$ of the feedstock. It is also possible to use milled peat. The implementation of this activity can significantly reduce the dusting of recently applied beaches dump. The efficiency dust suppression with due prompt response of staff of the enterprise can be up to $96 \%$. Thus, it is possible to reduce the total emissions of dust into the airdump to 246.5 tons/year to 10.2 tons/year.

\section{Acknowledgements}

Research was carried out with the support center of collective use high-tech equipment "CKP" National Mineral Resources University (Mining University).

\section{REFERENCES}

1. Danilov A.S., Smirnov Y.D., Pashkevich M.A. 2015. The System of the Ecological Monitoring of Environment which is Based on the Usage of UAV. Russian Journal of Ecology, 6 (1), 14-19.

2. Danilov A.S., Smirnov Y.D., Petrova T.A., Pashkevich M.A. 2015. Using drones of preconstruction monitoring conducting in mining enterprise.
International Journal of Ecology and Development, 30 (1), 24-35.

3. Paskevich M.A., Kremcheev E.A., Korelsky D.S., Petrova T.A., Smirnov Y.D. 2013. RF patent No. 2536789, Moscow, Federal Institute of Industrial Property.

4. Shtin S.M. 2005. Lake sapropel and their integrated development. Publisher Moscow Mining University.

5. Shuvalov Y.V. and Smirnov Y.D. 2006. RF patent No. 2277326. Moscow, Federal Instituteof Industrial Property.

6. Shuvalov Y.V., Bulbashev A.I., Smirnov Y.D., Rusak O.E. 2007. RF patent No. 2338355. Moscow, Federal Institute of Industrial Property.

7. Smirnov Y.D. and Ivanov A.V. 2013. Assessing the impact of the mine on the environment and ways to prevent the spread of major pollution. Anthropogenic transformation of the natural environment: scientific lecturing meeting memory N.F. Reimers and F.R. Shtilmark, 12-14 December 2013, Publisher Perm State University, Russia, 207-210.

8. Smirnov Y.D. and Ivanov A.V. 2013. Dust suppression process management in enterprises mineral complex. Problems of Geology and Exploitation of Mineral Resources, Proceedings of the XVII ${ }^{\text {th }}$ International Symposium Academician M.A. Usov, 7-11 April 2013, Publisher Tomsk State University, Russia, 547-548.

9. Vocelko S., Dankevich V., Dankevich L., Litvinchuk O., Patika V. 2011. New highly efficient sticky EPAA-10. Zerno, Vol. 2, 29-36.

10. Vocelko S., Gnidec V., Dankevich L., Litvinchuk O., Patika V. 2011. UA Patent No. 60637. Kiev, State Department of Intellectual Property. 